\title{
Konstruksi Sosial Remaja di Tamiang Layang pada Esoterisme Religio Magis Putri Mayang Sari
}

\author{
Yuel \\ Institut Agama Kristen Negeri Palangka Raya \\ yuelkin192@gmail.com
}

\begin{abstract}
This study aims to examine the phenomenon of religio magis putri mayang sari among Tamiang Layang Christian adolescents. The research method used is qualitative. The technique of collecting data by means of interviews, observation and documentation. The research subjects were students of SMAN 1 Tamiang Layang, caretakers of the tombs, and parents of students. The results showed that the socio-cultural construction of the Ma'anyan community towards the Puteri Mayang Rite as a social reality is an expression of Ma'anyan appreciation of the world and transcendent values are religio magis. Then, the Ma'anyan adolescent social construction of the Princess Mayang Rite was implemented in Christian Religious Education learning through interactive, inspirational, challenging learning strategies and participant observation as well as in multicultural learning. The social construction of Ma'anyan youth towards the Princess Mayang Rite contains an understanding of religious, social values, a sense of pride in one's own culture (local culture), and tolerance obtains support from educators. The results of the study recommend that Christian Religious Education teachers support the social construction of Ma'anyan adolescents so that they are conveyed in the learning process in the classroom.
\end{abstract}

Keywords: social construction; esotericism; religio magical; putri mayang sari

\begin{abstract}
Abstrak
Penelitian ini bertujuan untuk mengkaji fenomena religio magis putri mayang sari di kalangan remaja Kristen Tamiang Layang. Metode penelitian yang digunakan adalah kualitatif. Teknik pengumpulan data dengan wawancara, observasi, dan dokumentasi. Adapun subyek penelitian adalah siswa SMAN 1 Tamiang Layang, juru kunci makam, dan orang tua siswa. Hasil penelitian menunjukkan bahwa konstruksi sosial budaya masyarakat Ma'anyan terhadap Ritus Puteri Mayang sebagai realitas sosial adalah ungkapan penghayatan Ma'anyan tentang dunia dan nilai transenden bersifat religio magis. Kemudian, konstruksi sosial remaja Ma'anyan terhadap Ritus Puteri Mayang diimplementasikan pada pembelajaran Pendidikan Agama Kristen melalui strategi pembelajaran interaktif, inspiratif, menantang, dan observasi partisipan serta dalam pembelajaran multikultural. Konstruksi sosial remaja Ma'anyan terhadap Ritus Puteri Mayang mengandung pemahaman tentang nilai religius, sosial kemasyarakatan, ada rasa bangga terhadap kebudayaan sendiri (budaya lokal), dan toleransi memperoleh dukungan dari para pendidik. Hasil penelitian merekomendasikan agar guru Pendidikan Agama Kristen mendukung konstruksi sosial remaja Ma'anyan agar disampaikan dalam proses pembelajaran di kelas.
\end{abstract}

Kata Kunci: konstruksi sosial; esoterisme; religio magis; putri mayang sari 


\section{Pendahuluan}

Tulisan ini mengkaji fenomena religio magis putri mayang sari di kalangan remaja Kristen Tamiang Layang. Tidak dapat dipungkiri bahwa fenomena religio magis masih mewarnai kehidupan masyarakat, sekalipun dunia sudah mengandalkan modernitas dan realitas dalam tatanan masyarakat. Fenomena ini dapat dilihat semakin banyak dibicarakan hingga dapat disaksikan dalam acara-acara melalui media kemajuan zaman, sekalipun sulit untuk membuktikan kebenarannya berdasarkan pandangan rasional. Kini banyak orang melakukan praktek religio magis tidak lagi tersembunyi dan merambat kepada kalangan orang yang berpendidikan. Media masa telah bebas menyajikan esoterisme, kekuatan supranatural, gaib sakral, dan magis memasuki ruang publik. Praktek esoteris telah menjadikan tokoh sebagai allah lain dalam pandangan iman Kristen.

Tayangan acara praktik esoterisme di televisi serta kecanggihan komunikasi telah mampu mempresentasikan dunia gaib, misteri, dan magis yang tidak nyata menjadi nyata bagi publik. Secara visual televisi telah menjadi wahana hiburan, komunikasi, dan informasi sudah menjadikannya seolah-olah semuanya itu dunia nyata. Sejumlah tayangan acara di televisi yang menayangkan religio magis telah membuat esoteris sebagai dunia "rahasia, dan tersembunyi" menjadi tampak lebih konkrit. Dari dunia perdukunan juga muncul Ponari seorang dukun cilik yang memiliki batu untuk menyembuhkan. Serta peramal ekor gurita sakti "Paul" yang menjadi juru ramal pada permainan sepak bola piala dunia 2010 di Afrika Selatan.

Remaja di daerah Maanyan Tamiang Layang Kalimantan Tengah tidak asing lagi sehubungan praktik esoterisme. Esoterisme di kalangan masyarakat Maanyan dikenal ada tokoh yang luar biasa yaitu putri Manyang Sari. Kuburan Putri Mayang Sari sering menjadi tujuan kunjungan banyak orang. Ada ungkapan umum yang mengatakan belum berkunjung ke Tamiang Layang apa bila belum berkunjung ke makam Putri Mayang. Berdasarkan observasi awal terhadap salah satu siswa alumnus SMAN-1 Tamiyang Layang, mengungkapkan bahwa ia pernah berkunjung ke pemakaman Puteri Mayang Sari dan meminta sesuatu. Ia menjelaskan, dulu ibunya pernah meminta agar bisa membeli motor dan apabila permohonan atau permintaan tersebut dikabulkan maka mereka akan memberikan sesuatu. Penjelasan siswa remaja ini menunjukkan bahwa esoterisme di kalangan remaja tentang kuburan Putri Mayang Sari masih ada dan mempengaruhi kehidupan remaja Kristen.

Konstruksi pemahaman remaja Kristen Ma'anyan pada esoteris religio magis merupakan kajian menarik dalam Pendidikan Agama Kristen (PAK). Budaya religio magis sebagai properti kebudayaan masyarakat tidak menjadi asing sebagai sebuah realitas di kalangan masyarakat Maanyan terutama di sekitar Tamiang Layang. Namun bagi orang Kristen, esoteris menjadi persoalan karena menyangkut iman dan kebenaran yang dipercayai. Berangkat dari permasalahan tersebut, penelitian ini bertujuan untuk menganalisis konstruksi sosial remaja terkait ritus Putri Mayang Sari di SMA 1 Tamiang Layang, Kalimantan Tengah yang kemudian diimplementasikan pada pembelajaran Pendidikan Agama Kristen.

\section{Metode Penelitian}

Pendekatan yang digunakann pada penelitian ini adalah kualitatif dengan metode fenomenologi. Metode fenomenologi digunakan untuk memahami dan menginterpretasikan alasan-alasan tersembunyi di balik tindakan yang diamati. Fenomenologi merupakan tindakan individu melalui usaha mengungkapkkan perasaan, dan keinginan. Metode fenomenologi tidak hanya mengetahui apa yang diperbuat individu dalam kehidupan sosialnya tetapi juga pengalaman batin individu tersebut. Metode fenomenologi mengungkapkan ekpresi jiwa, ide, pengalaman penuh makna di balik tindakan individu 
yang teramati. Penelitian kualitatif metode fenomenologi memberi ruang kepada subjek penelitian mengungkapkan pandangan sendiri atau perspektif tentang esoteris religio magis pada putri Mayang Sari bagi suku Maanyan dilihat dari pandangan iman Kristen terutama teologi kontekstual yang mampu memberi sumbangan pada pembelajaran PAK untuk memahami PAK yang kontekstual.

Lokasi penelitian ini mengambil tempat di Sekolah Menengah Atas Negeri 1 (SMAN1) Tamiyang Layang, Kabupaten Barito Timur, Kalimantan Tengah. Waktu penelitian dimulai pada bulan April sampai dengan bulan Agustus 2019. Sumber data atau nara sumber dalam penelitian ini adalah : 5 (lima) siswa SMAN-1 Tamiyang Layang (Sa), 1 orang Juru Kunci (Jr), 2 orang tua siswa (Ot), 2 Orang Tokoh Masyarakat atau Demang dan Mantir Adat (Dmg dan Mtr), 1 orang Kepala Sekolah (KS), 1 orang Guru Pendidikan Agama Kristen (GPAK), 1 Orang Pendeta Jemaat 2 orang penatua Diakon. Pengumpulan data dalam penelitian ini ialah observasi, wawancara, dan dokumentasi. Observasi dilakukan dengan mengamati sendiri apa yang dilakukan oleh para pengunjung ke makam putri Mayang Sari di desa Jaar kabupaten Barito Timur yang terletak lima kilo meter dari pusat kota kabupaten Tamiang Layang. Wawancara yang dilakukan kepada kalangan masyarakat sebagai subjek penelitian tidak terjadi dalam satu hari sekaligus tergantung kepada kesediaan subjek peneliti untuk diwawancara. Dokumentasi dilakukan dengan mengumpulkan dokumen dari beberapa sumber yang berhubungan dengan Putri Mayang Sari yang menjadi masalah penelitian ini, baik menyangkut data tertulis maupun tidak tertulis (tradisi), maupun berupa poto-poto pendukung.

Teknik pengumpulan data dengan berpedoman pada pendapat Milles dan Huberman. Miles dan Heberman dalam Sugiyono, menjelaskan tahapan itu adalah sebagai berikut: ${ }^{1}$ pertama, reduksi data. Setelah memperoleh data di lapangan, peneliti membuat rangkungan memilih hal-hal yang pokok dan memfokuskan pada hal-hal yang penting berdasarkan data yang diperoleh menjadi suatu bentuk tulisan yang akan dianalisis. Peneliti mengkategorikan data pada hasil observasi dan wawancara serta membuat rangkuman. Kedua, penyajian data/data display. Setelah data direduksi, maka langkah berikutnya adalah mendisplay data, maka memudahkan untuk memahami apa yang terjadi serta merencanakan kerja selanjutnya berdasarkan apa yang dipahami. Selain menggunakan teks naratif, juga dapat berupa tabel, grafik, dan sejenisnya. Melalui penyajian data tersebut, maka data terorganisasikan, tersusun dalam pola hubungan, sehingga akan samakin mudah dipahami. Ketiga, penarikan kesimpulan. Kesimpulan berisi tentang uraian dari seluruh sub kategorisasi tema yang tercantum pada tabel kategorisasi dan pengkodean. Persoalan penelitian ini akan dikaji melalui hubungan antara objek dengan nalar sehingga menjadi pengetahuan, dimana hubungannya sangat berkaitan erat dimana objek yang ditelaah. Permasalahan tersebut selanjutnya akan digali dan dipaparkan sehingga menjadi pengetahuan untuk mengembangkan melakukan konstruksi sosial remaja maanyan yang berhubungan dengan Esoterisme Putri Mayang.

\section{Hasil dan Pembahasan}

\section{Hasil Penelitian}

\section{Esoterisme sebagai Fenomena Religi}

Esoterisme memiliki arti bersifat rahasia (tersembunyi). Esoteris merupakan pengajaran agama yang tidak diberikan kepada setiap orang. Pengajaran esoterisme hanya untuk lingkungan terbatas. Pengajaran tersebut untuk sejumlah kecil orang yang sudah mengembangkan kerohanian yang memadai untuk memahami ajaran itu, karena pengajaran esoterisme umumnya sukar dipahami. Dalam pengertian luas esoerisme merupakan aspek

\footnotetext{
1 Sugiyono, Metode Penelitian Pendidikan (Bandung: Alfa Beta, 2016), 338-345.
} 
metafisis dan dimensi instrinsik agama. Esoterisme terselubung dalam tindakan atau perilaku keagamaan bersifat eksoterik. Esoterisme berhubungan dengan hal-hal yang supranatural, sakral, gaib, misteri, adikodrati, kesaktian dan sejenisnya. Dalam pengertian luas, esoterisme merupakan aspek metafisis dan dimensi instrinsik agama. Esoterisme terselubung dalam tindakan atau perilaku keagamaan bersifat eksoterik. Esoterisme berhubungan dengan hal-hal yang supranatural, sakral, gaib, misteri, adikodrati, kesaktian dan sejenisnya.

Berikutnya ialah religi. Menurut Turrner, religi berasal dari istilah Latin, relegere dari relegere yang artinya mempersatukan, memanen, memeluk. ${ }^{2}$ Sedangkan religare dari ligare, bermakna mengikat atau mempersatukan. Istilah pertama merujuk pada dasar keagamaan semua kelompok manusia yang secara sosial hidup bersama. Sedangkan istilah kedua merujuk pada disiplin atau sistem moralitas yang diperlukan untuk mengontrol umat manusia dan membangun mentalitas teregulasi. Selanjutnya Frazer menjelaskan arti religi adalah keyakinan terhadap kekuatan yang secara langsung menaungi kehidupan manusia dan mengendalikan alam semesta. ${ }^{3}$ Religius terdiri dari dua elemen. Pertama, keyakinan pada kekuatan yang lebih tinggi daripada manusia dan upaya berdamai dengan kekuatan itu. Kedua, keyakinan terhadap keberadaan atau eksistensi kekutan tersebut. Kekuatan gaib yang diyakini berada di atas kekuatan manusia membuat manusia dengan keterbatasan dan kelemahannya merasa membutuhkan pertolongan dengan membina hubungan baik dengan kekuatan baik. Realitanya adalah sikap patuh terhadap perintah dan hal yang dilarang oleh kekuatan gaib. Keyakinan terhadap kekuatan gaib sebagai penentu nasib mengakibatkan manusia berusaha maksimal menjaga hubungan baik agar kesejahteraan dan kebahagiaannya terpelihara.

Pals berpendapat bahwa religi adalah sebuah sistem terpadu dari kepercayaan dan praktik yang berhubungan dengan hal sakral, yakni hal-hal yang terpisah, terlarang. ${ }^{4}$ Sementara itu, Durkheim menyatakan bahwa religius merupakan fenomena supranatural dan supernatural, dunia misteri, tidak diketahui, dan tidak dipahami. ${ }^{5}$ Dengan demikian, secara sederhana religi merupakan segala sistem perbuatan manusia untuk mencapai suatu maksud dengan suatu cara menyandarkan diri kepada kemauan dan kekuasaan makhlukmahkluk halus seperti roh, dewa, dan sebagainya yang menempati alam.

Religi memiliki beberapa unsur. Unsur-unsur tersebut menurut Arifin yaitu: 6 pertama, pengakuan terhadap adanya hubungan manusia dengan kekuatan gaib yang harus dipatuhi yang menguasai manusia mengikat pada suatu bentuk yang mengandung pengakuan pada sumber yang berada di luar manusia yang memengaruhi perbuatanperbuatannya. Kedua, kepercayaan pada suatu kekuatan gaib yang menimbulkan cara hidup tertentu. Ketiga, suatu sistem tingkah laku yang berasal dari kekuatan gaib. Menurut Koentjaraningrat, semua sistem religi di dunia berpusat kepada suatu konsep tentang hal yang gaib (mysterium) yang dianggap maha-dahsyat (tremendous) dan keramat abadi (sacred) oleh manusia. ${ }^{7}$ Sifat dari hal yang gaib serta keramat itu adalah maha abadi, maha-dahsyat, maha-adil, maha-bijaksana, tak terlihat, tak berobah, dan tak terbatas. Lebih lanjut, makhluk

\footnotetext{
2 Bryn Turrner, The Penguin Dictionary Of Sociology, Novany (Yogyakarta: Pustaka Pelajar, 2010), 470-471.

${ }^{3}$ James George Frazer, The Golden Bough A Study of Magic Anda Religion (New York: The Flonting Press, 2009), 124-125.

${ }^{4}$ Daniel L. Pals, Seven Theories of Religion: Dari Animisme EB Taylor Materialisme Karl Marx Hingga Antropologi Budaya C. Greetz (Yogyakarta: Qalam, 2001), 167.

${ }^{5}$ Emile Durkheim, The Elementary Forms of The Religious Life (London: Collier Macmillian Publisher, 1965), 39.

${ }^{6}$ Bambang Syamsul Arifin, Psikologi Agama (Bandung: Pustaka Setia, 2008), 14-16.

${ }^{7}$ Koentjaraningrat, Beberapa Pokok Antropologi Sosial (Jakarta: Dian Rakyat, 1990), 65.
} 
dan kekuatan menduduki dunia gaib adalah dewa-dewa yang baik maupun yang jahat serta makhluk-makhluk lain seperti ruh leluhur, kekuatan sakti yang bisa berguna maupun yang bisa menyebabkan bencana.

Adapun fungsi religi meliputi: edukasi, penyelamatan, pengawasan sosial, memupuk persaudaraan dan transformatif. ${ }^{3}$ Fungsi edukasi berhubungan dengan pendayagunaan nilai-nilai rohani sebagai hal pokok dalam kepercayaan untuk tujuan hidup dan rasa tanggung jawab kepada Tuhan. Fungsi peyelamatan adalah agama merupakan jaminan kepada manusia atas keselamatan dunia kini dan setelah kematian. Fungsi kontrol sosial adalah agama turut bertanggung jawab terhadap norma-norma sosial. Agama menyeleksi kaidah-kaidah sosial yang ada, mengukuhkan yang baik menolak kaidah-kaidah yang buruk agar ditinggalkan dan dianggap sebagai larangan serta mengadakan pengawasan yang ketat atas pelaksanaannya.

\section{Proses Konstruksi Sosial}

Proses konstruksi sosial melalui beberapa tahapan. Tahapan-tahapan tersebut adalah: pertama, eksternalisasi. Eksternalisasi merupakan pencurahan diri terhadap dunia sosio kultural. Menurut Riyanto, manusia merupakan makhluk konservatif yang memiliki kecenderungan repetitif atau mengulang-ngulang tindakannya. ${ }^{9}$ Manusia melakukan eksternalisasi secara terus menerus. Menurut Berger, hal itu disebabkan manusia harus mengalami perkembangan kepribadian dan perolehan budaya. ${ }^{10}$ Keadaan manusia yang belum selesai pada saat dilahirkan, membuat dirinya tidak terspesialisasi dari dunianya yang tidak terprogram. Dunia manusia adalah dunia yang dibentuk (dikonstruksi) oleh aktivitas manusia sendiri. Manusia harus membentuk dunianya sendiri dalam hubungannya dengan dunia. Dunia manusia yang dibentuk itu adalah kebudayaan yang tujuannya memberikan struktur-struktur kokoh yang sebelumnya tidak dimilikinya secara biologis. Manusialah yang membentuk struktur sehingga struktur-struktur itu bersifat tidak stabil dan selalu memiliki kemungkinan berubah. Itulah sebabnya konstruksi sosial bukan sematamata reproduksi kembali struktur yang ada dan terlahir dalam sejarah budaya suatu masyarakat. Menurut bahwa dalam konstruksi sosial ada mentalitas dan persepsi terhadap nilai budaya tentang waktu yang akan datang. ${ }^{11}$ Hal ini dapat dipahami mengapa kebudayaan selalu dihasilkan kembali oleh manusia.

Kedua, objektivasi. Objektivasi adalah proses yang mengendalikan institusi menjadi realitas. Perkembangan manusia dari usia anak hingga dewasa sangat ditentukan secara sosial. Semua aktivitas manusia yang terjadi dalam eksternalisasi mengalami proses pembiasaan (habitualisasi) yang kemudian mengalami pelembagaan (institusionalisasi). Pelembagaan menurut Berger berasal dari proses pembiasaan atas aktivitas manusia. ${ }^{12}$ Setiap tindakan yang sering diulangi, akan menjadi pola. Pembiasaan yang berupa pola, dapat dilakukan kembali di masa mendatang dengan cara yang sama ekonomisnya, dan juga dapat dilakukan dimana saja. Di balik pembiasaan juga sangat mungkin terjadi inovasi, namun proses pembiasaan mendahului sikap pelembagaan. Pelembagaan terjadi apabila ada representasi yang timbal balik dari tindakan-tindakan yang terbiasakan bagi berbagai tipe pelaku.

8 Liputo Solahudin, Religious Dan Psychological Well-Being (Malang: UIN Press, 2009), 15.

9 Yatim Riyanto, Paradigma Baru Pembelajaran (Jakarta: Kencana, 2009), 105.

${ }^{10} \mathrm{P}$. Berger dan T. Luckman, The Sosial Construction of Reality A Treatise in the Sosiology of Knowleadge (New York: Doubleday, 1991), 5-6.

${ }^{11}$ Koentjaraningrat, Beberapa Pokok Antropologi Sosial, 39.

12 Berger, The Sosial Construction of Reality A Treatise in the Sosiology of Knowleadge, 71. 
Ketiga, Internalisasi. Internalisasi adalah suatu pemahaman atau penafsiran individu secara langsung peristiwa objek sebagai pengungkapan makna. Dalam internalisasi individu mengidentifikasikan diri dengan berbagai lembaga sosial atau organisasi sosial di mana individu menjadi anggotanya, Internalisasi merupakan peresapan kembali realitas oleh manusia dan mentransferkkannya kembali dari struktur-struktur dunia objektif ke dalam struktur-struktur kesadaran objektif.

\section{Manusia sebagai Mahluk Yang Berbudaya (Human Sucio Antropologis)}

Permasalahan yang diteliti sebagaimana yang dipaparkan sebelumnya adalah tentang masalah teologi yang kontekstual dalam Kristen terutama dalam memandang Esoterisme yang terjadi sebagai bagian dari sistem kebudayaan yang berkembang di tengahtengah kehidupan Jemaat maupun sekolah setempat. Berdasarkan pemikiran itu, maka secara teoritis dalam penelitian ini dapat dikembangkan. Pertama, hubungan antara nilainilai budaya dengan teologi yang berkembang dalam ajaran Kekristenan. Kebudayaan yang membuat manusia menjadi sangat istimewa, membuat manusia berbeda dari binatang, tumbuh-tumbuhan dan mahluk-mahluk lainnya di dunia. Dalam Kamus Bahasa Indonesia Kontemporer, budaya merujuk pada tata cara hidup dari satu kelompok masyarakat tertentu yang lazimnya ditaati dan lakukan secara turun temurun.13 Menurut Koentjaraningrat, kebudayaan meliputi banyak hal yang di antaranya menyangkut tentang kebiasaan berpakaian, sikap kelakuan, cara menghormati orang tua, dan juga melakukan upacaraupacara keagamaan atau kepercayaan suku dan lain-lain. ${ }^{14}$ Termasuk juga tradisi penokohan terhadap kehebatan Puteri Mayang (Esoterisme).

Pengertian budaya tersebut, maka hubungan antara manusia dengan kebudayan saling mempengaruhi satu dengan yang lainnya. Dengan demikian, menurut Erward B. Tylor dalam Indra Jaya dalam bukunya Masyarakat dan Kebudayaan Manusia menjelaskan, kebudayaan dalam pengertiannya meliputi 2 (dua) pemahaman mendasar yaitu kebudayaan dalam pengertian materil yaitu suatu kebudayaan yang dihasilkan dalam masyarakat tertentu berupa kebudayaan yang bersifat kongkrit seperti benda-benda purbakala, alat-alat berburu dan bertani, artefaks-artefaks atau monument-monumen dan lain sebagainya. Sedangkan kebudayaan dalam pengertian non material yaitu suatu kebudayaan berupa sistem nilai atau etika (sistem adat-istiadat), pandangan dunia masyarakat setempat (world view), pandangan masyarakat terhadap lingkungannya (kosmologi), pemahaman masyarakat terhadap apa arti dan makna kehidupan setelah kematian (andragoni) dan termasuk keyakinan atau kepercayaan dalam agama manusia.

Kedua, hubungan Injil dan kebudayaan manusia. Hubungan antara Injil dan kebudayaan masih dalam ruang lingkup perdebatan yang panjang semenjak Kristen mulamula. Generasi baru kekristenan dewasa ini menempatkan persoalan antara Injil dan kebudayaan sebagai persoalan yang masih relevan dalam kehidupan gereja. Persoalan ini diangkat karena didasari pemahaman bahwa hubungan antara manusia dengan kebudayaan mustahil dipahami secara terpisah dengan masalah keyakinan dalam agama yang dianut oleh seorang individu atau kelompok.

Demikian halnya dengan orang Dayak Ma'anyan di Kalimantan Tengah. Misalnya, masih melaksakan tradisi esoterisme dengan berjiarah ke kuburan Putri Mayang, termasuk siswa SMAN-1 Tamiyang Layang dengan bernazar. Dalam Kamus Besar Bahasa Indonesia, bernazar adalah berjanji akan berbuat sesuatu jika maksud tercapai; misalnya jika seseorang datang dengan maksud meminta sesuatu keberuntungan dengan harapan apabila

13 W. Poerwadarminta, Kamus Besar Bahasa Indonesia (Jakarta: Balai Pustaka, 2011), 10.

${ }^{14}$ Koentjaraningrat, Beberapa Pokok Antropologi Sosial, 46. 
permintaan mereka terpenuhi maka mereka juga akan memberikan sesuatu. ${ }^{15}$ Tradisi jiarah ini sudah dilakukan secara turun-temurun.

Terkait hubungan Injil dan kebudayaan, Richard Neihbur seorang Antropolog menjelaskan, antara Kristus dan kebudayaan adalah dua hal yang berbeda. ${ }^{16}$ Kristus berkonfrontasi melawan kebudayaan dan hubungan keduanya tidak dapat diperdamaikan. Dalam konteks pemahaman ini, kebudayaan dianggap sebagai wujud dan produk masyarakat yang memiliki nilai-nilai bertentangan dengan ajaran Kristus. Kebudayaan merupakan nilai-nilai masyarakat kafir yang menjadi penghambat atau penghalang manusia berhubungan dengan Kristus, sehingga tidak ada hubungan antara kebudayaan dan Injil (sikap negatif terhadap adat). Artinya bahwa setiap kebudayaan manusia seperti adat istiadat, hukum adat, cara menyembah kepada yang dianggap kuasa "cara mengekspresikan Iman" yang telah tercipta turun temurun dari nenek moyang tidak selaras dengan Injil, sehingga setiap nilai-nilai serta prinsip yang telah diajarkan Kristus tidak bisa dipersatukan (bertolak belakang) dengan kebudayaan.

Selanjutnya, Richard Neihbur juga menjelaskan, bahwa antara Kristus dan kebudayaan memiliki relasi pemikiran yang sejajar, di mana Kristus berangkat dari kebudayaan. Dengan kata lain, bahwa Kristus adalah bagian dari kebudayaan (produk kebudayaan) lahir dalam kebudayaan Yahudi, dalam berbahasa mengunakan bahasa Ibrani dan Kristus juga sebagai pelaku dari kebudayaan itu sendiri. Dengan kata lain bahwa Kristus sebenarnya bukan meniadakan suatu kebudayaan manusia yang telah tercipta turun temurun, tetapi sebagai pemelihara, melestarikan dan menyempurnakan kebudayaan.

\section{Pembahasan}

Pembahasan hasil penelitian ini terbagi atas beberapa bagian terkait instrumen penelitian. Pertama, instrumen siapakah Putri Mayang Sari. Jawaban informan menerangkan bahwa Puteri Mayang adalah seorang putri kerajaan Banjar yang bernama Putri Mayang Sari. Beliau sangat dihormati oleh orang Ma'anyan. Beliau adalah saudara angkat Uria Mapas, yang meninggal dunia akibat sakit kuning di usia muda. Informan juga menjelaskan, Puteri Mayang Sari adalah puteri yang cantik, rambutnya panjang, orangnya ramah, banyak yang menyukai.

Danandjaja dalam artikel berjudul Mite Puteri Mayang di Kabupaten Barito Timur, menguraikan bahwa mitos atau mite (myth) adalah cerita yang mengisahkan tentang terjadinya alam semesta, dunia, manusia pertama, terjadinya maut, bentuk khas binatang, bentuk topografi, gejala alam dan sebagainya. ${ }^{17}$ Mite seringkali dipadang sebagai sejarah, sebab mite dapat dijadikan bahan untuk merekonstruksi sejarah yang mengadung unsurunsur pralogis. Mite dalam masyarakat Ma'anyan bersifat mitologi, dikatakan demikian karena mite yang ada hanya bersifat faktual bagi masyarakat Ma'anyan sebagai pemilik mite namun mite tersebut belum pernah dimuat dalam buku sejarah. Ma'anyan adalah salah satu suku Dayak yang tinggal di wilayah kabupaten Barito Timur, ibu kota di Tamiang Layang yang terletak antara 102' Lintang Utara dan 205' Lintang Selatan, 1140-1150 Bujur Timur (BPS Bartim, 2014: 3). Wilayah ini diapit oleh Kabupaten Barito Selatan di sebelah Utara, di sebelah Timur sebagian provinsi Kalimantan Selatan, dan di sebelah Barat berbatasan dengan Barito Selatan.

Berdasarkan data yang dikumpulkan, menjelaskan bahwa Putri Mayang Sari menurut sejarah lisan orang Dayak Ma'anyan, Mayang Sari yang adalah putri Sultan

15 Poerwadarminta, Kamus Besar Bahasa Indonesia.

${ }^{16}$ Richard Neihbur, Kristus Dan Kebudayaan (Jakarta: BPK Gunung Mulia, 2009), 56.

17 Danandjaja, Mite Puteri Mayang Di Kabupaten Barito Timur (Jakarta: Pustaka Utama, 2007),

51. 
Suriansyah yang bergelar Panembahan Batu Habang dari istri keduanya, Noorhayati. Putri Mayang Sari dilahirkan di Keraton Peristirahatan Kayu Tangi pada 13 Juni 1858, yang dalam penanggalan Dayak Ma'anyan disebut Wulan Kasawalas Paras Kajang Mammai. Sedangkan Noorhayati sendiri, menurut tradisi lisan orang Dayak Ma'anyan adalah perempuan Ma'anyan cucu dari Labai Lamiah, tokoh mubaligh Suku Dayak Ma'anyan.

Selanjutnya ada urusan apa seorang putri dari Kesultanan Banjar mau berada di kampung orang dayak yang sekarang bernama Ja'ar? Putri Mayang Sari diserahkan oleh Sultan Suriansyah kepada Uria Mapas, pemimpin dari tanah Ma'anyan di wilayah Jaar Sangarasi. Dituturkan, dalam kesalahpahaman Pangeran Suriansyah membunuh saudara Uria Mapas yang bernama Uria Rin'nyan yaitu pemimpin di wilayah Hadiwalang yang sekarang bernama Dayu. Akibatnya, Sultan Suriansyah terkena denda Adat atau disebut Pali, yaitu selain membayar sejumlah barang adat juga harus menyerahkan anaknya sebagai ganti orang yang dibunuhnya.

Mengapa harus menyerahkan perempuan? Mengapa bukan sang putra mahkota dari kerajaan Banjar saja yaitu Pangeran Rahmatulah? Dalam cerita di atas, data didapatkan dari tulisan Sutopo Ukip yang berjudul "Sejarah Banjar, Maanyan, dan Merina di Madagaskar" mengisahkan, saat Uria Rinyan datang ke Kesultanan banjar, ternyata istri Sultan Jatuh hati dan terjadi perselinghuhan. Hal itulah yang membuat Sultan membunuh Uria Rinyan dengan keris bermata intan, namun wakil Uria Rinyan Makarua'ng berhasil lolos dan melaporkan kepada orang-orang di kampungnya. Maka berangkatlah saudara Uria Rinyan, yaitu Uria Lana ke Banjarmasin, dan mengamuk di Nagara dengan menggunakan mandau yang bernama Lansar Tawomea. Sampai akhirnya Sultan Suriansyah meminta berdamai dan berjanji menyerahkan anaknya Puteri Mayang, sehingga saat itu pula nama Uria Lana menjadi Uria Mapas.

Puteri Mayang adalah tokoh mitos. Merujuk pemikiran Thomson ${ }^{18}$ dan Suseno ${ }^{19}$ tentang mitos, maka mitos Puteri Mayang adalah cerita sakral penghubung antara masyarakat Ma'anyan dengan hal-hal gaib, kekuatan adikodrati, misteri yang berada di luar jangkauan mereka. Roh Puteri Mayang diyakini sebagai kekuatan adikodrati dan misteri yang secara signifikan bermakna bagi kehidupan masyarakat Ma'anyan desa Jaar, sehingga rohnya dipuja. Roh Puteri Mayang dihormati dan diberi sesaji. Puteri Mayang dapat disebut penjaga kampung. Masyarakat Ma'anyan memuja makam Puteri Mayang. Makam Puteri Mayang ramai dikunjungi warga Ma'anyan bahkan juga dari luar untuk melakukan ritual.

Berdasarkan pengakuan juru kunci makam Puteri Mayang, menerangkan bahwa makam tersebut biasa dikunjungi oleh para pelancong, baik itu dari Pulau Kalimantan, maupun dari Pulau Jawa (Jakarta). Makam ini biasa dikunjungi, misalnya saat mereka yang bernazar memperoleh banyak padi. Mereka akan datang membawakan ayam, kambing, lamang. Orang Dayak memang sejak awal demikian. Dari sepuluh orang yang datang, ada tujuh orang yang terkabul sehingga banyak yang meyakini, atau asal percaya.

Roh Puteri Mayang merupakan kekuatan gaib yang diyakini menguasai kehidupan masyarakat Ma'anyan. Roh yang dipuja pada umumnya adalah roh dari orang yang diyakini sebagai tokoh masyarakat daerah atau tempat di mana orang tersebut tinggal. Semasa hidupnya Puteri Mayang tidak hanya sebagai tokoh yang memimpin tetapi juga sebagai menjadi pelindung masyarakat tersebut dari ancaman bahaya. Puteri Mayang adalah pemimpin yang mampu memberi ketentraman dan kesejahteraan hidup bagi masyarakat Ma'anyan. Setelah Puteri Mayang meninggal dalam pikiran mistis masyarakat Ma'anyan, rohnya masih diyakini hidup dan mengayomi setiap usaha masyarakat Ma'anyan

${ }_{18}$ Michael Thompson, Cultural Theory (San Fransisco: Westview Press, 1990).

${ }^{19}$ Franz Magnis Suseno, Etika Jawa: Sebuah Analisa Falsafi Tentang Kebijaksanaan Hidup Jawa (Jakarta: Gramedia, 1999). 
memenuhi kepentingan dan kebutuhan hidup. Roh Puteri Mayang dianggap memiliki kekuatan atau kesaktian.

Puteri Mayang bagi masyarakat Ma'anyan merupakan simbol kekuatan kosmis. Makam Puteri Mayang dianggap sebagai pusat kosmis yang menjaga dunia mereka agar tetap tenang, tenteram, tanpa perselisihan, dan pertentangan. Kosmologi Ma'anyan menunjukkan walaupun mereka lebih mengidentifikasi diri bukan Dayak Kaharingan tetapi kenyataannya diri mereka melekat etika Dayak, yakni mewujudkan harmonisasi kehidupan antara manusia dengan manusia, manusia dengan alam, dan manusia dengan Tuhan. ${ }^{20}$

Pertanyaan berikutnya ialah peristiwa atau kejadian apa saja yang pernah dialami warga Ma'anyan Desa Ja'ar terkait dengan Puteri Mayang? Menurut juru kunci, ada kejadian mistis di luar pikiran manusia, misalnya bisa melihat Sang Puteri dan istrinya bisa dirasuki oleh Putri Mayang. Dirasuki oleh puteri Mayang Sari biasanya terjadi saat malam Senin dan malam Jumat, di malam bulan purnama. Selain itu, Putri Mayang bisa menampakkan diri dengan berbagai rupa. Puteri Mayang dalam penglihatan, bisa hadir sebagai orang tua bongkok, itu pertanda bahwa ekonomi morat marit. Kalau hadir dalam rupa perempuan cantik, maka kehidupan sejahtera. Putri Mayang biasa dipanggil untuk menjaga kampung, agar jauh dari marabahaya. Suatu saat pernah menampakkan diri dengan pakaian kerajaan lengkap, yaitu pada saat kerusuhan di Kalimantan Tengah. Pakaian itu tanda Putri Mayang hadir dalam kewaspadaan untuk menjaga kampung.

Kejadian serupa juga dikisahkan oleh seorang siswa SMAN-1 Tamiyang Layang. Ia mengisahkan bahwa ibunya pernah melihat penampakan Putri Mayang. Ibu siswa tersebut bukan asli Jaar, saat pertama datang hajatnya mau kasih kain kuning, karena lupa ibunya melihat Puteri Mayang dalam mimpi dan sepertinya diminta untuk mengantar. Ibunya lalu mengantarnya. Siswa SMA ini mengungkapkan bahwa Putri Mayang dan orang-orang yang melaksanakan ritual tidak mengganggu.

Berdasaarkan kisah tentang peristiwa mistis berkaitan dengan Puteri Mayang yang dituturkan di atas, dapat disimpulkan bahwa cerita mistis itu sudah menjadi pengetahuan berdimensi kognitif dan normatif bagi masyarakat Ma'anyan. Peristiwa mistis berkaitan dengan Puteri Mayang dianggap cerita suci oleh warga desa. Warga Ma'anyan takut jika membicarakan hal-hal jelek tentang Puteri Mayang serta tidak mempercayai Puteri Mayang sebagai penguasa Desa Jaar. Hal ini dapat mengakibatkan prahara atau bencana bagi mereka, atau paling tidak akan mengakibatkan apa yang menjadi harapan akan permintaan mereka tidak terpenuhi.

Memahami isi cerita tentang kejadian mistis berkaitan dengan Puteri Mayang, mitos Puteri Mayang adalah cerita esoterisme sebagai realitas tertinggi yang berbeda dengan kenyataan biasa. Mitos Puteri Mayang mengandung ungkapan kenyataan dunia supernatural dan adikodrati sebagai dunia esoterisme yang berkuasa atas kehidupan masyarakat suku Ma'anyan. Mitos Puteri Mayang adalah representasi dari dunia tersebut. Mitos Puteri Mayang dianggap benar-benar terjadi dan suci oleh masyarakat Ma'anyan. Mitos Puteri Mayang sebagai hal sakral merupakan sesuatu di luar konsepsi rasional. Mitos Puteri Mayang sebagai hal sakral merupakan getaran dan pesona misteri.

Mitos Puteri Mayang mengandung kekuatan mutlak dan unsur maha kuasa atau kekuatan tertinggi yang tertanam dalam kesadaran warga Ma'anyan. Cerita tentang berbagai kejadian mistis berhubungan dengan Puteri Mayang mempertegas pemikiran bahwa hal yang terlihat dalam dunia sakral merupakan jenis dan sifat yang tidak tertukar

${ }^{20}$ Harun Hadiwiyono, Kebatinan Injil (Jakarta: BPK Gunung Mulia, 2009). 
oleh manusia yang menimbulkan rasa takut dan aneh. Pengalaman dengan hal sakral menimbulkan ketidakberdayaan penganutnya sekaligus mengandung penghambaan. ${ }^{21}$

Puteri Mayang dihayati sebagai sosok gaib yang berkehendak dan berkuasa atas kehidupan masyarakat suku Ma'anyan. Berbagai peristiwa yang terjadi di sekitar pemukiman masyarakat Ma'anyan baik yang menimpa warga Ma'anyan maupun warga lainnya dihayati sebagai kejadian nyata dari kehendak dan kuasa Puteri Mayang. Nasehat yang diberikan kepada siapapun yang berada di wilayah desa Ja'ar supaya tidak bersikap dan bertindak superioritas terhadap Puteri Mayang serta menganggap Puteri Mayang inferior menunjukan intensionalitas masyarakat Ma'anyan bukan cerita biasa.

Kedua, instrumen eksternalisasi, objektivasi dan internalisasi remaja Ma'anyan terhadap Ritus Puteri Mayang. Informan siswa alumnus SMAN-1 Tamiyang Layang menerangkan bahwa mereka pernah punya nadzar, mereka berkunjung ke pemakaman Puteri Mayang Sari dan meminta sesuatu. Dikisahkan, mereka dulu miskin dan ibunya meminta ke makam Puteri Mayang agar bisa membeli motor dan apabila permohonan atau permintaan tersebut dikabulkan maka mereka akan memberikan sesuatu. Sebelum mereka berdo'a meminta sesuatu juru kunci terlebih dahulu melakukan ritus memanggil roh Puteri Mayang agar bisa hadir saat itu dan sekaligus memberitahukan bahwa ada tamu datang ingin menemui Puteri Mayang. Permohonan mereka terkabulkan, dan mereka berhasil bisa membeli sepeda motor baru. Informan lainnya, siswa SMAN-1 Tamiyang Layang menjelaskan bahwa mereka sekeluarga bersama orang tua dan om-nya yang kuliah di Amuntai pernah bernadzar ke makam Puteri Mayang. Mereka berdo'a di sana meminta agar om-nya bisa lulus ujian.

Berdasarkan keterangan yang diperoleh dari informan dapat disimpulkan bahwa pengetahuan dan pemahaman tentang Ritus Puteri Mayang sebagai realitas sosial sudah mereka kenal sejak kecil atau sejak masih anak-anak. Dalam hal ini keluarga memegang peran penting dalam menanamkan pengetahuan dan pemahaman tentang hal tersebut. Mitos Puteri Mayang dan ritusnya sudah ada sebelum remaja Ma'anyan Jaar lahir ke dunia ini. Kebudayaan rohani Ma'anyan itu melalui sosialisasi pengetahuan bagi mereka sejak masih anak-anak hingga saat ini. Remaja Ma'anyan Jaar menghadapai kenyataan Ritus Puteri Mayang dan mitosnya sebagai kenyataan sehari-hari yang dihadapi dan dialami.

Cerita penuturan dan ritus Puteri Mayang yang dikatakan sudah ada sejak dahulu sebelum remaja Ma'anyan Ja'ar dilahirkan dan hingga kini masih hidup dalam sistem pengetahuan masyarakat serta menjadi realitas sosial. Hal ini menurut Berger, merupakan deskripsi bahwa remaja Ma' anyan mengalami apa yang disebut reifikasi. ${ }^{22}$ Remaja Ma'anyan mempunyai pemahaman Ritus Puteri Mayang dan mitosnya seolah-olah bukan produk masyarakat. Mereka melupakan suatu kenyataan bahwa masyarakat Ma'anyan sendirilah yang telah menciptakan dunia manusia dan selanjutnya diallektika antara manusia yang memproduksi dan produknya sudah hilang dalam kesadaran.

Sejak dilahirkan remaja Ma'anyan Ja'ar mengalami secara terus-menerus transformasi pengertahuan, nilai, dan norma yang terkandung dalam ritus Puteri Mayang. Transformasi itu terjadi melalui sosialisasi. Pola sosialisasi yang terjadi di masyarakat Ma'anyan adalah kebiasaan orang tua selalu mengajak anak-cucu mengikuti ritus Puteri Mayang. Tindakan orang tua ini merujuk pemikiran Berger, untuk mengenalkan anak-anak Ma'anyan kepada definisi-definisi paling mendasar dari situasi sosial Dayak Ma'anyan.23 Keluarga menjadi medium penting eksternalisasi, objektivasi, dan internalisasi pengetahuan, 1996).

${ }^{21}$ Thomas O'dea, Sosiologi Agama Suatu Pengenalan Awal (Jakarta: Raja Grafindo Persada,

22 Berger, The Sosial Construction of Reality A Treatise in the Sosiology of Knowleadge.

23 Ibid. 
tindakan, dan nilai esoterisme religio magis Dayak Ma'anyan kepada anak-anak mereka. Keluarga Dayak Ma'anyan memiliki peran penting dalam personalisasi pengetahuan, sikap, nilai, dan norma yang terdapat dalam Ritus Puteri Mayang. Keluarga Dayak Man'anyan menjadi wadah utama dan agen pertama pensosialisasian kultur Ma'anyan kepada anakanak Ma'anyan sebab keluarga adalah dunia pertama kali menyentuh kehidupan anak-anak.

Horace Bushnell dalam Daniel Nuhamara menjelaskan, hendaknya orang tua memiliki iman itu bagi dirinya sendiri terlebih dahulu, lalu ajarlah itu kepada anak-anak dengan jalan memberi contoh kehidupan yang riil, ajarkanlah itu dengan contoh kehidupan, oleh karena sebenarnya tidak ada cara lain untuk mengajarkannya. ${ }^{24}$ Keluarga Dayak Ma'anyan merupakan inspirasi bagi anak-anak. Anak-anak Dayak Ma'anyan mendapatkan pelajaran berbagai hal yang ada dalam keluarga, tanpa disadari bahwa hal yang terjadi di keluarga memberi pengaruh besar bagi kehidupan generasi berikutnya. Sosialisi merupakan proses atau pembiasaan atau habitualisasi. Pembiasaan anak-anak Dayak Ma'anyan terhadap ritus Puteri Mayang sebagai dunia esoterisme religio magis membentuk struktur mental atau kognitif yang berguna bagi kehidupan sosial mereka. Remaja Ma'anyan merasakan, memahami, menyadari dan bertindak terhadap dunia sosial dan kebudayaan rohani masyarakatnya. Hal ini berarti remaja Dayak Ma'anyan sejak anak-anak mengalami apa yang dinamakan Ritzer sebagai habitualisasi (pembiasaan). ${ }^{25}$

Remaja Ma'anyan sepanjang hidupnya mengalami sosialisasi primer dan sekunder seiring dengan pertumbuhan dan perkembangan fisik maupun psikisnya. Sosialisasi primer adalah internalisasi yang berlangsung ketika mereka masih anak-anak, sedang sosialisasi sekunder yakni internalisasi yang dialaminya saat ini yakni remaja Ma' anyan memesuki usia dewasa. Sosialisasi remaja Ma'anyan berlangsung sepanjang hayat sejak lahir hingga mereka meninggal. Pada tahap sosialisasi primer remaja Ma'anyan mengalami pembudayaan atau enkulturasi Ritus Puteri Mayang sebagai esoterisme religio magis yang terjadi agak dipaksakan. Pada perkembangan kognitif sensorik motor, pra-operasional, dan operasional konkrit remaja Máanyan pada masa anak-anak belum belajar secara lebih sadar untuk menerima atau menolak nilai-nilai atau anjuran-anjuran dari orang tua atau masyarakatnya. Penyerapan nilai esoterisme religio magis oleh remaja Ma'anyan pada masa kanak-anak tejadi secara imitatif. Penyerapan ini merupakan proses pembelajaran figuratif. ${ }^{26}$

Ritus Puteri Mayang dengan segala makna simbolik yang terdapat di dalamnya bagi remaja Ma'anyan di masa anak-anak adalah fakta sosial. Pada masa anak-anak remaja Ma'anyan belum mampu mengkonseptualisasikan kebudayaan rohani Ma'anyan sebagai wujud kebudayaan ide melalui kesadaran berpikir sehingga terbentuk suatu ideologi dalam dirinya. Kebudayaan rohani masyarakat Ma'anyan diterimanya begitu saja. Ritus Puteri Mayang hadir dan diterima dalam kesadaran mereka tanpa perlu dibuktikan terlebih dahulu. Ritus Puteri Mayang sebagai realitas kehidupan sehari-hari bagi remaja Ma' anyan pada masa anak-anak bersifat menekan dan kenyataan ini dianggap sebagai hal wajar dan umumnya diterima begitu saja.

Sosialisasi esoterisme ritus Puteri Mayang sebagai religio magis Ma'anyan dimulai sejak anak-anak itu penting sekali. Sebagaimana ditegaskan Berger bahwa sosialisasi berfungsi bagi pemahaman mengenai kehidupan bersama sebagai hal yang maknawi dari kenyataan sosial. ${ }^{27}$ Sejak kecil remaja Ma'anyan belajar memahami, pengetahuan, perilaku, nilai, dan norma budaya esoterisme religio magis. Tanpa pemahaman sejak kecil tentang

17.

${ }^{24}$ Daniel Nuhamara, Pembimbing Pendidikan Agama Kristen (Bandung: Jurnal Info Media, 2009),

25 George Ritzer, Sosiologikal Theory (USA: Mc-Graw Hill Companies, 1996).

26 Paul Suparno, Teori Perkembangan Kognitif Jean Peaget (Yogyakarta: Kanisius, 2001).

27 Berger, The Sosial Construction of Reality A Treatise in the Sosiology of Knowleadge. 
aturan dan teknik yang ketat dalam pranata sosial esoterisme religio magis Ma'anyan beserta makna simboliknya sebagai kenyataan sosial. Ritus Puteri Mayang sebagai fenomena esoterisme religio magis akan kehilangan makna dan tujuan perilaku itu sendiri. Kehilangan makna akan berakibat ritus Puteri Mayang tidak memberi efek kejiwaan sama sekali kepada remaja Ma'anyan. Transformasi pengetahuan, nilai, dan norma esoterisme religio magis dan pemahaman tentang hal tersebut sejak remaja Ma'anyan berusia anak-anak penting untuk kelestarian ritus Puteri Mayang sebagai inti religi Ma'anyan.

Selanjutnya, Bagaimana pandangan remaja Ma'anyan Ja'ar terhadap tradisi Ritual Puteri Mayang sebagai kenyataan hidup sehari-hari dalam masyarakat? Berdasarkan jawaban atas pertanyaan yang disampaikan kepada remaja Ma'anyan, jawaban dapat digolongkan menjadi dua yaitu remaja Ma'anyan yang akomodatif dan remaja Ma'anyan yang loyal terhadap kebudayaan rohani Ma'anyan. Golongan pertama, yaitu kelompok akomodatif. Informan siswa SMAN-1 Tamiyang Layang menjelaskan pandangannya terhadap Ritual Puteri Mayang yang ada di desanya yakni Desa Ja'ar Kabupaten Barito Timur. Ia menjelaskan, ia pernah berziarah ke makam Puteri Mayang lebih dua kali, tepatnya ke sungai bersama dengan teman untuk mandi. Sungai itu kayanya sungai tempat puteri Mayang Sari biasanya mandi. Ia juga pernah ke sana bersama orang tua, sekaligus ziarah ke makam leluhur. Ia tidak yakin Puteri Mayang bisa menjamin kehidupan, karena ia Kristen. Ia tidak pernah hajat karena ia tidak yakin.

Hal senada juga dijelaskan oleh remaja Ma'anyan lainnya. Remaja bersangkutan menjelaskan, ia pernah ke sana lebih dua kali berziarah ke makam Puteri Mayang. Ia pergi ke sana bersama dengan lima orang temannya untuk mandi. Ia juga pernah ke sana bersama kerabat jauh yang datang dan ingin melihat makam. Saat ke sana, mereka diingatkan oleh penjaga sebelumnya (juru kinci) agar tidak ribut saat mandi. Remaja tersebut tidak yakin Putri Mayang bisa menjamin kehidupan. Keberadaannya pun antara percaya dan tidak. Ia tidak pernah hajat karena ia tidak yakin. Bagi remaja tersebut, yang menjamin kehidupan adalah Tuhan. Orang tua dan keluarga tidak ada yang memegang teguh ritual Puteri Mayang Sari, dan tidak pernah memohon apapun juga padanya.

Golongan remaja kedua adalah kelompok loyal. Menurut informan juru kunci, bahwa Makam Puteri Mayang ini biasa dikunjungi oleh para pelancong, baik itu dari Pulau Kalimantan dan Pulau Jawa (Jakarta). Makam ini biasa dikunjungi misalnya saat mereka yang bernazar memperoleh banyak padi. Mereka akan datang membawakan ayam, kambing, dan lamang. Orang Dayak memang sejak awal demikian. Kalau dari sepuluh orang yang datang, ada tujuh orang yang terkabul sehingga banyak yang meyakini, asal percaya. Selanjutnya menurut juru kunci makam, tentang siapa saja mengunjungi Makam Puteri Mayang menjelaskan bahwa Para Pelancong, para pejabat untuk bernazar, bidan supaya klinik bagus, pelajar supaya lulus ujian, setiap yang bernazar berdoa sesuai agama masing-masing, tanpa dibatasi suku bangsa semua boleh datang. Bahkan Ir. Tor Andrea dari Madagaskar pernah datang ke Makam Puteri Mayang. Ir. Soetopo juga yang memugar Makam Puteri Mayang Sari sesuai dengan nazar yang ia buat. Tujuan berziarah untuk mendapatkan keberhasilan. Petani agar berhasil, pejabat agar sukses dan pelajar supaya lulus ujian.

\section{Pendidikan Multikultural dalam Pembelajaran Pendidikan Agama Kristen}

Masyarakat Desa Jaar Barito Timur adalah masyarakat yang multikultural namun rentan dengan kesalahpahaman, dikarenakan pihak mayoritas yakni umat Kristiani memiliki kecenderungan memandang umat berkepercayaan lain sebagai kafir. Dalam kondisi sosial masyarakat demikian, maka pluralisme agama merupakan wacana yang penting untuk dikembangkan di tengah masyarakat, termasuk di dunia pendidikan. Dalam mata pelajaran Pendidikan Agama Kristen seyogyanya diperlukan upaya mengembangkan 
materi dan metode pembelajaran yang mampu menumbuhkan sikap toleran beragama di kalangan siswanya.

Dengan memperhatikan situasi di tengah masyarakat desa Jaar Barito Timur, diperlukan pendekatan teologi kontekstual. Adanya situasi sosio religious masyarakat yang membutuhkan pemecahan masalah, sehubungan dengan kondisi masyarakat yang bersifat multikultural, yang menjadikan wilayah ini rentan dengan salah paham, yang diakibatkan penduduknya memandang fenomena esoterisme religio magi Puteri Mayang Sari dari kacamata yang berbeda. Jika kebanyakan penduduk asli desa Jaar begitu menjunjung tinggi tradisi setempat dan menjadikan makam Puteri Mayang sebagai tempat yang sakral, maka penduduk pendatang, pun kelompok umat Kristiani tertentu dengan pemahaman ekslusifnya memandang tradisi masyarakat itu sebagai bentuk marginalisasi simbolis dan ketidaktaatan kepada Tuhan. Pendekatan teologis yang kontekstual diperlukan dalam upaya menghindari kesalahpahaman serta meningkatkan sikap saling menghargai antar pemeluk agama dan kepercayaan.

Di tengah masyarakat desa Jaar Barito Timur, setiap bentuk kebudayaan, dan kepercayaan yang menjadi bagian dari budaya masyarakat, adalah baik adanya. Dalam hal ini Kekristenan harus mengembangkan sikap toleran dalam perwujudan paham pluralisme di tengah kehidupan kesehariannya, termasuk di dunia pendidikan Kristen. Dalam hal inilah Kristus datang untuk memperbaharui, menyempurnakan, dan mentrasformasi serta menguduskan kebudayaan. Kebudayaan dan pola pendidikan di antara siswa Kristen yang semula mengembangkan pola mayoritas (umat Kristen) sebagai pihak yang kebenaran Tuhan. Sementara pihak lain (penganut kepercayaan agama setempat) sebagai pihak yang kafir harus ditranformasi. Kekristenan seharusnya menjadi pembawa shalom dan pihak yang memprakarsai sikap toleransi antar agama di wilayah tersebut. Sikap domiman dan memonopoli kebenaran adalah sikap yang harus disingkirkan, dan diganti dengan sikap penghargaan pada cara dan kebebasan setiap orang dalam beribadah kepada Tuhan. Dalam hal inilah pola pembelajaran Pendidikan Agama Kristen diharapkan dapat meningkatkan kesadaran siswa melalui pengalaman empirisnya dalam kehidupannya di sekolah, suatu wilayah pendidikan yang mana siswa mengenal kenyataan perbedaan secara nyata.

Dalam hal ini, model pembelajaran multikultural dalam mata pelajaran Pendidikan Agama Kristen tidak boleh diabaikan. Dengan kondisi multikultural dari masyarakat di desa Jaar Kabupaten Barito Timur, maka pola pendidikan multikultural adalah solusi yang harus dikembangkan. Dalam hal ini konsep mendasar, generalisasi, dan teori dalam mata pelajaran/disiplin ilmu Pendidikan Agama Kristen yang toleran kepada setiap penganut agama dan kepercayaan dikembangkan dan diimplementasikan dalam mata pembelajaran, baik itu secara teori maupun praktik. Prestasi akademik diukur dari kemampuan siswa memahami pentingnya penghargaan terhadap sesama di tengah keberagamaan masyarakat. Sikap toleran juga di kembangkan di tengah lingkungan sekolah, tidak hanya di antara siswa, tapi juga seluruh pihak yang ada di sekolah, termasuk melalui proses interaksi yang penuh persaudaraan antara siswa, guru, dan staf sekolah. Pengembangan paham pluralisme agama, maka sebagai integrasi sosial diantara umat beragama agar dapat hidup bersama (koeksistensi) antar agama (dalam arti yang luas) yang berbeda-beda dalam satu komunitas dapat ditingkatkan. Dalam hal ini Kekristenan tetap mempertahankan ciri-ciri spesifik ajaran agamanya. Sikap toleransi terhadap keberagaman, sejatinya juga merupakan perwujudan dari kasih kepada sesama yang adalah pengajaran utama dalam Kekristenan. Sikap mengasihi dan menghormati setiap pribadi dalam keberagaman suku, ras, dan agama tersebut adalah jawaban bagi permasalahan di tengah masyarakat di Desa Jaar Barito Timur. 


\section{Implikasi}

Penelitian ritus Puteri Mayang sebagai religio magis remaja Dayak Ma'anyan ini memberikan beberapa implikasi. Pertama, pemahaman teologis dari sudut pembelajaran Pendidikan Agama Kristen tentang keyakinan kepada Tuhan sangat penting dimiliki oleh remaja ayang adalah siswa SMAN 1 Tamiang Layang. Taks Matius 4: 10 menyatakan bahwa "Engkau harus menyembah Tuhan, Allahmu." Pemahaman yang kuat akan menolong siswa untuk memiliki prinsip hidup dan tidak gampang percaya pada hal-hal yang terkait mitos. Kedua, siswa SMAN 1 Tamiang Layang tidak perlu ikut-ikutan untuk berziarah atau berkunjung ke makam Putri Mayang, apalagi datang untuk memanjatkan permohonan. Hal ini penting, oleh kareja remaja Kristen adalah remaja yang percaya kepada Tuhan.

\section{Rekomendasi untuk Penelitian Lanjutan}

Penelitian ini perlu diperkaya dengan penelitian lanjutan. Konstruksi sosial remaja Ma'anyan terhadap esoterisme religio magis bisa dikembangkan sebagai bagian dari pendidikan karakter. Dalam konteks ke-Bhinekaan dengan keanekaragaman sosialbudayanya integrasi sosial dalam kehidupan berbangsa dan bernegara membutuhkan kesadaran bertoleransi, kooperatif, dan kepedulian sosial. Penerapan konstruksi sosial remaja Ma'anyan terhadap esoterisme religio magis pada pembelajaran PAK juga dapat dikembangkan dalam rangka membangun budaya sekolah yang kondusif untuk terciptanya iklim moral yang memperkokoh Persatuan dan Kesatuan Bangsa.

\section{Kesimpulan}

Berdasarkan hasil penelitian dan pembahasan yang sudah dilakukan, maka dapat diambil beberapa pemahaman sebagai kesimpulan adalah sebagai berikut: pertama, konstruksi sosial budaya masyarakat Ma'anyan terhadap Ritus Puteri Mayang sebagai realitas sosial adalah ungkapan penghayatan Ma'anyan tentang dunia dan nilai transenden bersifat religio magi. Pada umumnya kebanyakan masyarakat Dayak Ma'anyan mendukung dan setia melaksanakan ritus. Ritus Puteri Mayang dikonstruksi memiliki mekanisme mistis bagi terciptanya tertib sosial. Sekalipun secara perlahan terdapat anggota masyarakat Ma'anyan yang mulai meninggalkan tradisi Ritus Puteri Mayang, namun tidak sepenuhnya keadaan itu menghilangkan citra tatanan kehidupan sosial budaya bahwa Ma'anyan masih kuat diliputi dunia magis.

Kedua, konstruksi sosial remaja Ma'anyan terhadap Ritus Puteri Mayang diimplementasikan pada pembelajaran Pendidikan Agama Kristen (PAK). Pembelajaran PAK melalui strategi pembelajaran interaktif, inspiratif, menantang, dan observasi partisipan dan pembelajaran multikultural. Konstruksi sosial remaja Ma'anyan terhadap Ritus Puteri Mayang mengandung pemahaman tentang nilai religius, sosial kemasyarakatan, ada rasa bangga terhadap kebudayaan sendiri (budaya lokal), dan toleransi memperoleh dukungan dari para pendidik. Para guru PAK mendukung konstruksi sosial remaja Ma'anyan itu bisa disampaikan di mata pelajaran PAK sekalipun ada rasa kekawatiran dari beberapa pendidik apabila disampaikan akan terjadi transformasi dan internalisasi nilai-nilai magis.

\section{Rujukan}

Arifin, Bambang Syamsul. Psikologi Agama. Bandung: Pustaka Setia, 2008.

Berger, P dan T. Luckman. The Sosial Construction of Reality A Treatise in the Sosiology of Knowleadge. New York: Doubleday, 1991.

Danandjaja. Mite Puteri Mayang Di Kabupaten Barito Timur. Jakarta: Pustaka Utama, 2007.

Durkheim, Emile. The Elementary Forms of The Religious Life. London: Collier Macmillian Publisher, 1965.

Frazer, James George. The Golden Bough A Study of Magic Anda Religion. New York: The 
Flonting Press, 2009.

Hadiwiyono, Harun. Kebatinan Injil. Jakarta: BPK Gunung Mulia, 2009.

Koentjaraningrat. Beberapa Pokok Antropologi Sosial. Jakarta: Dian Rakyat, 1990.

Neihbur, Richard. Kristus Dan Kebudayaan. Jakarta: BPK Gunung Mulia, 2009.

Nuhamara, Daniel. Pembimbing Pendidikan Agama Kristen. Bandung: Jurnal Info Media, 2009.

O'dea, Thomas. Sosiologi Agama Suatu Pengenalan Awal. Jakarta: Raja Grafindo Persada, 1996.

Pals, Daniel L. Seven Theories of Religion: Dari Animisme EB Taylor Materialisme Karl Marx Hingga Antropologi Budaya C. Greetz. Yogyakarta: Qalam, 2001.

Poerwadarminta, W. Kamus Besar Bahasa Indonesia. Jakarta: Balai Pustaka, 2011.

Ritzer, George. Sosiologikal Theory. USA: Mc-Graw Hill Companies, 1996.

Riyanto, Yatim. Paradigma Baru Pembelajaran. Jakarta: Kencana, 2009.

Solahudin, Liputo. Religious Dan Psychological Well-Being. Malang: UIN Press, 2009.

Sugiyono. Metode Penelitian Pendidikan. Bandung: Alfa Beta, 2016.

Suparno, Paul. Teori Perkembangan Kognitif Jean Peaget. Yogyakarta: Kanisius, 2001.

Suseno, Franz Magnis. Etika Jawa: Sebuah Analisa Falsafi Tentang Kebijaksanaan Hidup Jawa. Jakarta: Gramedia, 1999.

Thompson, Michael. Cultural Theory. San Fransisco: Westview Press, 1990.

Turrner, Bryn. The Penguin Dictionary Of Sociology, Novany. Yogyakarta: Pustaka Pelajar, 2010. 